\title{
UNIVERSITYOF
}

FORWARD

THINKING

WESTMINSTER用

WestminsterResearch

http://www.westminster.ac.uk/westminsterresearch

\section{The Contribution of International Humanitarian Law to the \\ Development of the Law of International Responsibility Regarding Obligations Erga Omnes and Erga Omnes Partes \\ Longobardo, $\mathrm{M}$.}

This is a pre-copy edited, author-produced PDF of an article accepted for publication in the Journal of Conflict and Security Law following peer review.

The definitive publisher-authenticated version of Longobardo, M. (2018) The Contribution of International Humanitarian Law to the Development of the Law of International Responsibility Regarding Obligations Regarding Obligations Erga Omnes and Erga Omnes Partes, Journal of Conflict and Security Law, 23 (3), pp. 383-404 is available online at:

https://dx.doi.org/10.1093/jcsl/kry026

The WestminsterResearch online digital archive at the University of Westminster aims to make the research output of the University available to a wider audience. Copyright and Moral Rights remain with the authors and/or copyright owners.

Whilst further distribution of specific materials from within this archive is forbidden, you may freely distribute the URL of WestminsterResearch: ((http://westminsterresearch.wmin.ac.uk/).

In case of abuse or copyright appearing without permission e-mail repository@westminster.ac.uk 


\title{
THE CONTRIBUTION OF INTERNATIONAL HUMANITARIAN LAW TO THE DEVELOPMENT OF THE LAW OF INTERNATIONAL RESPONSIBILITY REGARDING OBLIGATIONS ERGA OMNES AND ERGA OMNES PARTES
}

\author{
Marco Longobardo*
}

\section{Introduction}

Despite some academic attention on the applicability of the law of international responsibility to international humanitarian law (IHL) violations, ${ }^{1}$ scant attention has been devoted to the influence of IHL on the development of the law of international responsibility. This essay explores this field, and in particular the development of rules related to breaches of obligations erga omnes and obligations erga omnes partes. This analysis focuses on the rules protecting civilians and persons hors de combat (so-called 'Geneva law') applicable to international armed conflicts. It argues that, since the aftermath of the Second World War, IHL has provided for some specific consequences regarding serious violations that may be seen as a precursor to the current law of state responsibility regarding obligations erga omnes and obligations erga omnes partes, ${ }^{2}$ as

\footnotetext{
* Research Fellow and Visiting Lecturer, University of Westminster. I wish to thank Lawrence HillCawthorne, Kubo Mačák, Maria Irene Papa, and Marco Roscini for their comments on previous drafts, and the participants to the Expert Roundtable on the Impact of the Law of Armed Conflict on General International Law, University of Exeter, 22-23 September 2016 for their remarks on my presentation on this topic. The usual disclaimers apply. Internet references were last accessed on 30 May 2018 when the paper was completed.

${ }^{1}$ See, e.g., Pierre d'Argent, Les réparations de guerre en droit international public: la responsabilité internationale des États à l'épreuve de la guerre (Bruylant/LGDJ 2002); Marco Sassòli, 'State Responsibility for Violations of International Humanitarian Law' (2002) 84 IRRC 401.

${ }^{2}$ On the concept of obligations erga omnes and erga omnes partes generally, see Paolo Picone, 'Obblighi reciproci ed obblighi erga omnes degli Stati nel campo della protezione internazionale dell'ambiente marino dall'inquinamento' in Vincenzo Starace (ed), Diritto internazionale e protezione dell'ambiente marino (Giuffrè 1983) 15 (reprinted, along with other contributions on this topic by the same author, in
} 
developed by the International Law Commission (ILC) for many decades and finalised in the authoritative - albeit non-binding - 2001 Draft Articles on Responsibility of States (DARS). ${ }^{3}$ Since the four 1949 Geneva Conventions ${ }^{4}$ have been ratified by every state in the world, so that it is difficult to separate the treaty obligations (some of which are considered obligations erga omnes partes) from the corresponding customary obligations (some of which are considered obligations erga omnes) for the purposes of this study, ${ }^{5}$ this author will refer simultaneously to the 1949 Geneva Conventions qua treaties and to the corresponding rules of customary international law. With regard to the 1977 First Additional Protocol (API), only its provisions reflecting customary international law may be seen as embodying obligations erga omnes, while some of its treaty provisions may be seen as examples of obligations erga omnes partes. ${ }^{6}$

The article opens with a brief overview of the concepts of obligations erga omnes and erga omnes partes (section II), and goes on to demonstrate that IHL comprises obligations erga omnes and erga omnes partes (section III). The article then demonstrates that the reactions to serious violations of obligations erga omnes and erga omnes partes

Paolo Picone, Comunità internazionale e obblighi erga omnes (3rd edn, Jovene 2013) 1); Maurizio Ragazzi, The Concept of International Obligations Erga Omnes (OUP 1997); Christian J Tams, Enforcing Obligations Erga Omnes in International Law (CUP 2005); Giorgio Gaja, 'The Protection of General Interests in the International Community' [2012] 364 RCADI 9.

${ }^{3}$ Draft Articles on Responsibility of States for Internationally Wrongful Acts with Commentaries [2001] ILCY vol II, Part Two 31 (DARS).

${ }^{4}$ Geneva Convention for the Amelioration of the Condition of the Wounded and Sick in Armed Forces in the Field (First Geneva Convention), 12 August 1949, 75 UNTS 31; Geneva Convention for the Amelioration of the Condition of Wounded, Sick and Shipwrecked Members of Armed Forces at Sea (Second Geneva Convention), 12 August 1949, 75 UNTS 85; Geneva Convention Relative to the Treatment of Prisoners of War (Third Geneva Convention), 12 August 1949, 75 UNTS 13; Geneva Convention Relative to the Protection of Civilian Persons in Time of War (Fourth Geneva Convention), 12 August 1949, 75 UNTS 287.

${ }^{5}$ On the differences between the regimes pertaining to obligations erga omnes and obligations erga omnes partes, see Maria Irene Papa, 'Interesse ad agire davanti alla Corte internazionale di giustizia e tutela dei valori collettivi nella sentenza sul caso Belgio c Senegal' (2013) 7 Diritti umani e diritto internazionale 79, 86-95; Paolo Picone, 'La responsabilità degli Stati tra codificazione e sviluppo progressivo della materia' (2016) 99 Rivista di diritto internazionale (RDI) 751, 756-758.

${ }^{6}$ Protocol Additional to the Geneva Conventions of 12 August 1949, and relating to the Protection of Victims of International Armed Conflicts (Protocol I), 8 June 1977, 1125 UNTS 3. 
envisaged by the DARS already existed with regard to serious IHL violations (section IV).

\title{
II. Obligations Erga Omnes and Obligations Erga Omnes Partes
}

In 1970, the International Court of Justice (ICJ) introduced the concept of obligations erga omnes in the international law debate for the first time. ${ }^{7}$ According to a very famous dictum:

\begin{abstract}
[A]n essential distinction should be drawn between the obligations of a State towards the international community as a whole, and those arising vis-à-vis another State in the field of diplomatic protection. By their very nature the former are the concern of all States. In view of the importance of the rights involved, all States can be held to have a legal interest in their protection; they are obligations erga omnes. ${ }^{8}$
\end{abstract}

Accordingly, obligations erga omnes are those international customary obligations that are the concern of every state since they are owed towards the international community as a whole, rather than towards one or more states. ${ }^{9}$ Similarly, obligations erga omnes partes (sometimes called erga omnes contractantes) are those treaty obligations owed towards a group of states parties to the same treaty, which all have a legal interest in

\footnotetext{
${ }^{7}$ The ICJ did not create obligations erga omnes, but rather, some regional treaties protecting minorities between the First World War and the Second World War alluded to the concept of community interests, as partially noted in some individual opinions of judges of the Permanent Court of International Justice (see Tarcisio Gazzini, 'The Protection of Minorities at the Origins of the Notion of Erga Omnes Obligations' in Andreas R Ziegler, Julie Kuffer (eds), Les Minorités et le Droit - Minorities and the Law (Schulthess 2016) 13).

${ }^{8}$ Barcelona Traction, Light and Power Company, Limited (Second Phase Judgment) [1970] ICJ Reports, para 33. On the legacy of this dictum, see See Christian J Tams and Antonios Tzanakopoulos, 'Barcelona Traction at 40: The ICJ as an Agent of Legal Development' (2010) 23 LJIL 781.

${ }^{9}$ See ICTY, Prosecutor v Anto Furundzija, IT-95-17/1-T, 10 December 1998, para 151; Institut de Droit international, Krakow session, Resolution of 27 August 2005, Article 1.
} 
respecting the rules embodied therein. ${ }^{10}$ The core element of these kinds of obligations is the fact that the legal interest in their compliance is common to and shared between a number of states or every state in the international community. ${ }^{11}$ Accordingly, they are a manifestation of the shift of the international community from bilateral and multilateral relations towards common concerns and interests. ${ }^{12}$ Obligations erga omnes are also partially different from jus cogens: though every jus cogens norm produces obligations erga omnes, not every obligation erga omnes is a jus cogens norm. In brief, peremptory law concerns hierarchy between rules, while the notion of obligations erga omnes focuses on the holders of the corresponding legal interests. ${ }^{13}$

The ILC has explored the role of obligations erga omnes from the perspective of state responsibility since 1976, when the Special Rapporteur Roberto Ago supported the adoption of Draft Article 19 addressing the so-called international crimes of states, which were implicitly based on serious violations of obligations erga omnes. ${ }^{14}$ This provision

10 For more on the classification of international obligations, see Linos-Alexander Sicilianos, 'The Classification of Obligations and the Multilateral Dimension of the Relations of International Responsibility' (2002) 13 EJIL 1127; Joost Pauwelyn, 'A Typology of Multilateral Treaty Obligations: Are WTO Obligations Bilateral or Collective in Nature?' (2003) 14 EJIL 907, 909-925.

${ }^{11}$ Legal scholarship is divided between those who believe that the implementation of obligations erga omnes partes by individual states is linked to a process of hierarchisation of the international community, and those who consider that individual states may implement obligations erga omnes in the framework of a decentralised international community. For an overview of this debate, see Bonafé, The Relationship Between State and Individual Responsibility for International Crimes (Martinus Nijhoff 2009) 23-24, fn 37; Alessandra Gianelli, 'Il contributo della dottrina italiana al tema della responsibilità internazionale degli Stati per fatto illecito: qualche osservazione' (2016) 99 RDI 1042, 1055-1056.

12 On this topic, see eg Bruno Simma, 'From Bilateralism to Community Interest in International Law' [1994-VI] 250 RCADI 217.

${ }^{13}$ See DARS, Commentaries to Chapter III, para 7. Previously, this distinction has been emphasised by José B Acosta Estévez, 'Normas de ius cogens, efecto erga omnes, crimen internacional y la teoría de los círculos concéntricos' (1995) 11 Anuario de derecho internacional 3, 12-15; Simma (n 12) 300; Denis Alland, 'Countermeasures of General Interest' (2002) 13 EJIL 1221, 1237. For more on this, see Paolo Picone, 'The Distinction between Jus Cogens and Obligations Erga Omnes' in Enzo Cannizzaro (ed), The Law of Treaties Beyond the Vienna Convention (OUP 2011) 411.

${ }^{14}$ See 'Report of the International Law Commission on Its 28th Session' [1976-II] YILC 75. The same report goes on to affirm that 'The criterion formulated in paragraph 2 of article 19 has two aspects. One is the requirement that the obligation breached shall, by virtue of its content, be essential for the protection of fundamental interests of the international community; the other, which complements the first and provides a guarantee that is essential in such a delicate matter, makes the international community as a whole 
was intended to be the basis of an aggravated regime of international responsibility for the commission of international crimes of state - an issue that triggered a significant scholarly debate. ${ }^{15}$ In 2001, the new Special Rapporteur, James Crawford, abolished the distinction between international crimes and delicts, and based the aggravated regime on serious violations of jus cogens. ${ }^{16}$ However, obligations erga omnes did not disappear from the ILC's articles, but rather, they, along with obligations erga omnes partes, are implicitly mentioned in Articles 42(b) and 48(1) DARS. ${ }^{17}$ Article 42(b) considers that states 'specially affected' by violations of obligations 'owed to [...] a group of states including that state [obligations erga omnes partes], or the international community as a whole [obligations erga omnes]' are injured state under the law of international

responsible for judging whether the obligation is essential and, accordingly, whether its breach is of a "criminal" nature' (ibid, 119). This appears to be the definition of obligations erga omnes pursuant to the Barcelona Traction case, which is mentioned by the same report as one of the most relevant judgments regarding international crimes (ibid, at 99). The same report rejects the equation between jus cogens violations and international crimes ('It would be wrong simply to conclude that any breach of an obligation deriving from a peremptory norm of international law is an international crime and that only the breach of an obligation having this origin can constitute such a crime', ibid, 119-120). The conclusion that international crimes of states are based on violations of obligations erga omnes is also based on the fact that the additional consequences of these violations, which are addressed subsequently in this section, affect every state in the international community; accordingly, if every state is affected at the level of secondary rules (ie rules on state responsibility) by the breach of these obligations, at the level of primary rules, the obligations at the basis of international crimes must be relevant not only for individual states, but rather, for every state in the international community as well (as affirmed by Picone, 'Obblighi' (n 2) 4953). This conclusion is supported by the special rapporteur Arangio-Ruiz, who affirmed that the Commission considered that '[a] crime justifies the adoption of countermeasures [...] not only on the part of the State, if any, primarily injured by the breach, but also of any other State in any way injured by the wrongful act' ('Fifth report on State responsibility, by Mr Gaetano Arangio-Ruiz, Special Rapporteur' [1993-II] YILC para 127).

${ }^{15}$ See, e.g., Joseph HH Weiler, Antonio Cassese, Marina Spinedi (eds), International Crimes of State: A Critical Analysis of the ILC'S Draft Article 19 on State Responsibility (de Gruyter 1989); André de Hoogh, Obligations Erga Omnes and International Crimes (Kluwer Law International 1996); Georges Abi-Saab, 'The Uses of Article 19' (1999) 10 EJIL 339.

${ }^{16}$ See Chapter III of Part 2 DARS and the accompanying commentary. See also James Crawford, State Responsibility: The General Part (CUP 2013) 390-394.

${ }^{17}$ On the ongoing relevance of obligations erga omnes in the DARS, see Paolo Picone, 'Obblighi erga omnes e codificazione della responsabilità degli Stati' (2005) 88 RDI 893; Linos-Alexander Sicilianos, 'L'influence des droits de l'homme sur la structure du droit international, deuxième partie: Les conséquences structurelles de la hiérarchisation' (2012) 116 RGDIP 242, 245-251. 
responsibility. Article 48(1) DARS, in line with previous case law, ${ }^{18}$ addresses the right of any state that cannot be qualified as injured under Article 42 DARS, in relation violations of obligations 'owed to a group of states including that state, and [...] established for the protection of a collective interest of the group' (obligations erga omnes partes), and obligations 'owed to the international community as a whole' (obligations erga omnes); these states, which may be identified as 'indirectly affected states' ${ }^{19}$ may invoke the responsibility of another state, and may claim cessation of the wrongful act and assurances of non-repetition, as well as performance of the obligation of reparation on behalf of the injured state or the beneficiaries of the violated obligation. ${ }^{20}$

It is still unclear whether obligations erga omnes and obligations erga omnes partes allow indirectly affected states to adopt countermeasures in cases of serious violations. The ILC acknowledged the existence of certain state practice, but considered it to be sparse and limited. ${ }^{21}$ Consequently, Article 54 DARS only affirms that indirectly affected states may adopt 'lawful measures against that State to ensure cessation of the breach and reparation in the interest of the injured State or of the beneficiaries of the obligation breached', without clarifying the meaning of 'lawful measures'. It has been suggested that this expression refers to countermeasures that are admissible under customary international law, so that the adjective 'lawful' would not refer to acts per se lawful, but rather, to measures that would be unlawful except for the fact that they are adopted as countermeasures; the opposite interpretation, according to which Article 54 refers only to acts that are per se legal, would render the provision superfluous because it would only restate the proposition that international law allows states to engage in non-prohibited

\footnotetext{
${ }^{18}$ See ICTY (n 9) para 151.

19 The expression 'indirectly affected states' is used instead of 'non-injured states' when referring to obligations erga omnes and obligations erga omnes partes because, under their very definitions, every state in the international community or every state party to certain treaties is injured in case of violations of these kinds of obligations. Accordingly, the DARS terminology appears inaccurate.

${ }^{20}$ See Art 48 DARS, and the accompanying commentaries; Institut de Droit international (n 9) Articles 2 and 5(a).

${ }^{21}$ DARS, Commentary to Art 54, paras 3-7.
} 
actions. ${ }^{22}$ Consequently, state practice and opinio juris must be analysed in order to verify whether such countermeasures are permissible. According to a number of scholars, there is sufficient uniform state practice to affirm that peaceful countermeasures may be adopted by indirectly affected states, ${ }^{23}$ while the possibility of using force as a countermeasure against violations of obligations erga omnes is more uncertain: although this solution has been considered lawful in certain specific circumstances by some scholars, ${ }^{24}$ and is debated in relation to the use of force under the doctrine of the Responsibility to Protect, ${ }^{25}$ the ban on the use of force beyond the limited exceptions within the UN Charter is still considered to be a cornerstone of contemporary international law. ${ }^{26}$ Accordingly, forcible countermeasures are generally considered unlawful. ${ }^{27}$

22 See Picone, 'Obblighi erga omnes e codificazione' (n 17) 940; Linos-Alexander Sicilianos, 'Countermeasures in Response to Grave Violations of Obligations Owed to the International Community' in James Crawford, Alain Pellet, Simon Olleson (eds), The Law of International Responsibility (OUP 2010) 1137, 1144-1148.

${ }^{23}$ See Pierre-Marie Dupuy, 'Observations sur la pratique récente des "sanctions" de l'illicite' (1983) 87 RGDIP 505; Linos-Alexander Sicilianos, Les réactions décentralisées à l'illicite: des contre-mesures à la légitime défense (LGDJ 1990) 155-174; Jochen A Frowein, 'Reactions by Not Directly Affected States to Breaches of Public International Law' [1994-IV] 248 RCADI 345, 405-422; Tams (n 2) 207-249; Elena Katselli Proukaki, The Problem of Enforcement in International Law: Countermeasures, the Non-injured State and the Idea of International Community (Routledge 2009) 90-209; Martin Dawidowicz, Third-Party Countermeasures in International Law (CUP 2017). See also Institut de Droit international (n 9) Article $5(\mathrm{c})$.

${ }^{24}$ See Antonio Cassese, 'Ex Iniuria Ius Oritur: Are We Moving towards International Legitimation of Forcible Humanitarian Countermeasures in the World Community? (1999) 10 EJIL 23, 29; Paolo Picone, 'La "guerra del Kosovo" e il diritto internazionale generale' (2000) 83 RDI 309; Id, 'Unilateralismo e guerra contro l'ISIS' (2015) 98 RDI 5.

${ }^{25}$ See Paolo Picone, 'Recensione a: Christopher Verlage, Responsibility to Protect (Mohr Siebeck 2009)' 93 RDI 287; Marco Longobardo, 'Genocide, Obligations Erga Omnes, and the Responsibility to Protect: Remarks on a Complex Convergence' (2015) 19 IJHR 1199; Francesco Francioni, 'Responsibility to Protect in the Age of Global Terror: A Methodological Reassessment' (2016) 51 The International Spectator 19.

${ }^{26}$ See generally James Crawford, Rowan Nicholson, 'The Continued Relevance of Traditional Rules and Institutions Relating to the Use of Force' in Marc Weller (ed), The Oxford Handbook of the Use of Force in International Law (OUP 2015) 86.

${ }^{27}$ See eg Art 50(1)(a) DARS. See also Frowein (n 23) 414; Christian J Tams, 'Individual States as Guardians of Community Interests' in Ulrich Fastenrath et al (eds), From Bilateralism to Community Interests. Essays in Honour of Judge Bruno Simma (OUP 2011) 379, 388. 
Article 41 DARS pertains to obligations erga omnes and erga omnes partes as well, even if a superficial reading of DARS may be misleading because Article 40 DARS refers to jus cogens. However, until 2000, all the Special Rapporteurs after Roberto Ago had considered obligations erga omnes to be relevant for the aggravated regime of international responsibility; ${ }^{28}$ this idea is so rooted in international law that the ICJ in its Israeli Wall advisory opinion applied Article 41(2) DARS on the basis of the existence of serious violations of obligations erga omnes (including some IHL rules), affirming that every state is under a duty not to recognise the situation created by the construction of the Israeli wall. ${ }^{29}$ Accordingly, Article 41 DARS may also be seen as codifying certain consequences of serious violations of obligations erga omnes as well.

In recent years, the concept of obligations erga omnes and obligations erga omnes partes and the rules pertaining to the consequences of their violations have been applied a number of occasions before international courts. Apart from the aforementioned 2004 ICJ's advisory opinion, which considered that the wall built by Israel in the OPT violates certain obligations erga omnes (some IHL rules and the principle of self-determination of peoples), ${ }^{30}$ in 2006 , the ICJ, recalling its own past case law, ${ }^{31}$ considered the duties to prevent and punish genocide to be obligations erga omnes. ${ }^{32}$ Similarly, in 2007, the Court

\footnotetext{
${ }^{28}$ See Part II.

${ }^{29}$ Legal Consequences of the Construction of a Wall in the Occupied Palestinian Territory (Advisory Opinion) [2004] ICJ Reports, para 159. Although the ICJ's reference to 'intransgressible principles of international customary law' might be an allusion to jus cogens, clearly the ICJ focuses on obligations erga omnes (see Wall opinion (n 29), para 157). It is unclear whether the Court deliberately emphasised the role of obligations erga omnes with regard to the aggravated regime of state responsibility in opposition to the ILC's perspective centred on serious violations of jus cogens (see Andrea Bianchi, 'Dismantling the Wall: The ICJ's Advisory Opinion and Its Likely Impact on International Law' [2004] 47 GYIL 343, 380-383), or whether the Court simply manifested its famous reluctance to employ the concept of jus cogens (Marco Pertile, "Legal Consequences of the Construction of a Wall in the Occupied Palestinian Territory": A Missed Opportunity for International Humanitarian Law?' (2004) 14 Italian YIL 121, 155).

${ }^{30}$ Wall opinion (n 29), paras 155-160.

${ }^{31}$ Reservations to the Genocide Convention (Advisory Opinion) [1951] ICJ Reports, 23; Application of the Convention on the Prevention and Punishment of the Crime of Genocide (Bosnia and Herzegovina $v$ Serbia and Montenegro) (Judgment) [1996] ICJ Reports, para 31.

${ }^{32}$ Armed Activities on the Territory of the Congo (New Application: 2002) (DRC v Rwanda) (Judgment) [2006] ICJ Reports, para 64. This qualification was considered irrelevant in order to overcome the principle
} 
implicitly recognised that the duties to prevent and punish genocide are obligations erga omnes, ${ }^{33}$ while in 2015 they were considered to be obligations erga omnes partes. ${ }^{34}$ Additionally, in 2011, the International Tribunal for the Law of the Sea acknowledged that Article 137(2) UNCLOS embodies obligations erga omnes, and that, consequently, '[e]ach State Party may also be entitled to claim compensation' pursuant to Article 48 DARS. ${ }^{35}$ Moreover, in 2012, the ICJ declared that the 1984 UN Convention against Torture embodies obligations erga omnes partes and that, accordingly, every contracting state has locus standi before an international tribunal with jurisdiction over a case regarding violations of such obligations. ${ }^{36}$ In addition, obligations erga omnes and obligations erga omnes partes played a major role in the Australian strategy in the Whaling case before the ICJ - even if the Court did not have an opportunity to address this issue since Japan had not challenged Australian locus standi. ${ }^{37}$ Finally, the Marshall Islands claimed locus standi on the basis of obligations erga omnes partes allegedly embodied in Article 6 of the 1968 Non-Proliferation of Nuclear Weapons Treaty and in the allegedly corresponding customary obligations erga omnes. ${ }^{38}$

of consent in the settlement of international disputes (ibid), following the opinion expressed in East Timor (Portugal v Australia) (Judgment) [1995] ICJ Reports, para 29.

${ }^{33}$ Application of the Convention on the Prevention and Punishment of the Crime of Genocide (Bosnia and Herzegovina v Serbia and Montenegro) (Judgment) [2007] ICJ Reports, paras 147 and 185 (note that the Court did not challenge the qualification of obligations erga omnes provided by the applicant).

${ }^{34}$ Application of the Convention on the Prevention and Punishment of the Crime of Genocide (Croatia $v$ Serbia) (Judgment) [2015] ICJ Reports, para 87.

${ }^{35}$ Responsibilities and Obligations of States Sponsoring Persons and Entities with Respect to Activities in the Area (Advisory Opinion) [2011] ITLOS Reports, para 180.

${ }^{36}$ Questions Relating to the Obligation to Prosecute or Extradite (Belgium v Senegal) (Judgment) [2012] ICJ Reports, paras 68-70. For some remarks, see Papa (n 5) 5.

37 See Malgosia Fitzmaurice, Whaling and International Law (CUP 2015) 109-113; Christian J Tams, 'Roads Not Taken, Opportunities Missed: Procedural and Jurisdictional Questions Sidestepped in the Whaling Judgment' in Malgosia Fitzmaurice, Dai Tamada (eds), Whaling in the Antarctic: Significance and Implications of the ICJ Judgment (Brill 2016) 193, 201-211, and the references cited therein. The ICJ decided the case on Whaling in the Antarctic (Australia v Japan: New Zealand intervening) (Judgment) [2014] ICJ Reports.

38 Obligations concerning Negotiations relating to Cessation of the Nuclear Arms Race and to Nuclear Disarmament (Marshall Islands v Pakistan) (Application instituting proceedings against Pakistan) [2014] ICJ Reports, paras 35-36; Obligations concerning Negotiations relating to Cessation of the Nuclear Arms Race and to Nuclear Disarmament (Marshall Islands $v$ India) (Application instituting proceedings against 
On the basis of the international case law examined, it is clear that obligations erga omnes and obligations erga omnes partes are highly topical issues in the law of state responsibility. Accordingly, it is important to understand the origins of such concepts and of the law of state responsibility pertaining to their violations.

\section{Some Indicators of Community Interests in IHL}

\section{a. Preliminary Remarks}

At its origins, IHL was characterised by reciprocity. According to Article 2 of the 1907 Hague Regulations, the rules embodied therein 'do not apply except between Contracting powers, and then only if all the belligerents are parties to the Convention' ${ }^{39}$ (the so-called si omnes clause). This assumption reflected the esprit du temp, according to which the law of war was concerned only with the interests of the belligerents in the framework of bilateral relations (or series of bilateral relations if there were more than two belligerents). It is clear why the Hague Regulations pay scant heed to the protection of civilians, but rather, focus on states' interests.

However, with the evolution of the law of war, the protection of the civilian population became the cornerstone of the jus in bello, which faced a progressive process of humanisation. ${ }^{40}$ This process, which was marked by the adoption of the 1949 Geneva Conventions, was further developed in the 1977 API, and caused the demise of the $s i$

the Republic of India) [2014] Reports, paras 40-41; Obligations concerning Negotiations relating to Cessation of the Nuclear Arms Race and to Nuclear Disarmament (Marshall Islands v UK) (Application instituting proceedings against the United Kingdom of Great Britain and Northern Ireland) [2014] ICJ Reports, paras 85-86.

${ }^{39}$ Convention (IV) respecting the Laws and Customs of War on Land and its annex: Regulations concerning the Laws and Customs of War on Land, 205 CTS 277. See also Art 24 Convention for the Amelioration of the Condition of the Wounded and Sick in Armies in the Field, 11 LNTS 440.

${ }^{40}$ See, generally, Theodor Meron, 'The Humanization of Humanitarian Law' (2000) 94 AJIL 239. 
omnes clause even with respect to the Hague Regulations, ${ }^{41}$ which are applicable as a matter of customary international law irrespective of reciprocity. ${ }^{42}$

In keeping with this trend, and as will be shown in the subsequent sections, in contemporary IHL, the obligations regarding the protection of certain groups are owed towards the international community as a whole, and every state has a legal interest in other states' compliance. In other words, as shown by a brief examination of some relevant provisions, contemporary IHL clearly embodies obligations erga omnes and obligations erga omnes partes.

\section{b. Common Article 1 of the 1949 Geneva Conventions}

According to common Article 1 of the 1959 Geneva Conventions, '[ $t$ ]he High Contracting Parties undertake to respect and to ensure respect' for the 1949 Geneva Conventions 'in all circumstances'. This provision is restated in the API, and it is considered to be part of customary law. ${ }^{43}$ There has been an extensive debate regarding the meaning of the words 'ensure respect'; although some scholars have argued that these provisions add nothing to the duty to respect the Conventions and to prevent private actors from violating them, ${ }^{44}$ it has also been asserted that they emphasise the fact that the 1949 Geneva Conventions embody obligations erga omnes and obligations erga omnes partes. ${ }^{45}$ Consequently, it is possible to identify an external dimension of common Article 1 of the 1949 Geneva

\footnotetext{
${ }^{41}$ The si omnes clause is ruled out by common Art 2(3) of the 1949 Geneva Conventions. More generally on the demise of reciprocity in IHL, see Mark Osiel, The End of Reciprocity (CUP 2009) 31-150.

${ }^{42}$ See Wall opinion (n 29) para 89.

${ }^{43}$ Art 1(1) API; Rule 144 in Jean-Marie Henckaerts, Louise Doswald-Beck (eds), Customary International Humanitarian Law (CUP 2005) (Customary IHL) vol I 509-513.

${ }^{44}$ See Carlo Focarelli, 'Common Article 1 of the 1949 Geneva Conventions: A Soap Bubble?' (2010) 21 EJIL 125.

${ }^{45}$ See Luigi Condorelli, Laurence Boisson De Chazournes: 'Quelques remarques à propos de l'obligation des États de «respecter et faire respecter» le droit international humanitaire «en toutes circonstances»' in Christophe Swinarski (ed), Études en l'honneur de Jean Pictet (ICRC 1984) 17; and 'Common Article 1 of the Geneva Conventions Revisited: Protecting Collective Interests' (2000) 82 IRRC 67.
} 
Conventions that shows that states have a legal interest in other states' compliance with the rules embodied in the conventions beyond a strict regime of reciprocity. ${ }^{46}$

This seems the better interpretation because of the duty to interpret in an effective way every provision of a treaty and in light of the significant subsequent practice regarding the interpretation of these provisions. ${ }^{47}$ Additionally, it is noteworthy that the words 'ensure respect' were introduced through a proposal of the International Committee of the Red Cross (ICRC), which aimed at the creation of additional obligations for states beyond their own commitment to respect the Conventions. ${ }^{48}$ International case law confirms the interpretation that common Article 1 of the 1949 Geneva Conventions refers also to conduct in relation to other states. First, in the Wall opinion, the ICJ strengthened its finding regarding the consequences of Israeli violations of certain obligations erga omnes by invoking common Article 1 of the 1949 Geneva Conventions. ${ }^{49}$ Moreover, the ICJ invoked briefly common Article 1 of the 1949 Geneva Conventions in the Nicaragua case in order to spell out US duties regarding a conflict to which it was not a party,

\footnotetext{
46 ibid. See also, among others, Jean Pictet (ed), Commentary: IV Geneva Convention Relative to the Protection of Civilian Persons in Time of War (ICRC 1958) 15; Paolo Benvenuti, 'Ensuring Observance of International Humanitarian Law: Function, Extent and Limits of the Obligation of Third States to Ensure Respect for International Humanitarian Law' [1989-90] Yearbook of the International Institute of Humanitarian Law 27; Knut Dörmann, Jose Serralvo, 'Common Article 1 to the Geneva Conventions and the Obligation to Prevent International Humanitarian Law Violations' (2014) 96 IRRC 707; Robin Gei $\beta$, 'The Obligation to Respect and to Ensure Respect for the Conventions' in Andrea Clapham, Paola Gaeta, Marco Sassòli (eds), The 1949 Geneva Conventions: A Commentary (OUP 2015) 111; Jean-Marie Henckaerts, 'Article 1: Respect and Ensure Respect' in ICRC, Updated Commentary on the First Geneva Convention (CUP 2016), 35-67; Andrea Breslin, 'A Reflection on the Legal Obligation for Third States to Ensure Respect for IHL' (2017) 22 JCSL 5.

${ }^{47}$ See Condorelli, Boisson De Chazournes, 'Quelques' (n 45) 18 (emphasising the role of effective interpretation). For the position according to which common Article 1, though not drafted with the aim to emphasise such general interest, evolved into such through subsequent practice, see Frits Kalshoven, 'The Undertaking to Respect and Ensure Respect in All Circumstances: From Tiny Seed to Ripening Fruit' [1999] 2 YIHL 3.

${ }^{48}$ See Final Record of the Diplomatic Conference of Geneva of 1949 vol II, section B, 53. For an overview on the travaux préparatoires, see Dörmann, Serralvo (n 46) 712-716

${ }^{49}$ Wall opinion (n 29) paras 158-159. The link between obligations erga omnes and common Article 1 of the 1949 Geneva Conventions is acknowledged - albeit skeptically — in the Separate Opinion of Judge Higgins, para 39, and, with approval, by the Opinion of Advocate General Wathelet, Case C-266/16, 10 January 2018, paras. 238-239.
} 
emphasising that the duties to respect and to ensure respect are separate. ${ }^{50}$ Furthermore, Judge Simma, in his Separate Opinion in the ICJ's 2005 DRC v. Uganda case, linked common Article 1 of the 1949 Geneva Conventions to the possibilities for every state party to IHL conventions to bring a claim before the ICJ ${ }^{51}$ thus anticipating the ICJ's dictum on obligations erga omnes partes in the Belgium $v$ Senegal case. ${ }^{52}$ In addition, the ICTY had invoked common Article 1 of the 1949 Geneva Conventions to rule out reciprocity in IHL, referring to 'absolute obligations [...] that are unconditional', ${ }^{53}$ just after having recalled that its own case law had qualified those obligations as obligations erga omnes. ${ }^{54}$

\section{c. The 'Big Eye' of the International Community regarding IHL Compliance}

Another important feature of contemporary IHL is that there are a number of mechanisms to ensure compliance with its rules on the basis of international monitoring and scrutiny. Even if these mechanisms do not work in a satisfactory way, ${ }^{55}$ the existence of nonbelligerents' interests in IHL compliance suggests that the structure of these obligations is not merely bilateral.

First, the Protecting Powers, formalised in the 1929 Geneva Convention on Prisoners of War, are relevant. Pursuant to Article 2(c) API, 'Protecting Power means a neutral or other State not a Party to the conflict which has been designated by a Party to the conflict

\footnotetext{
${ }^{50}$ Military and Paramilitary Activities in and against Nicaragua (Nicaragua v USA) (Judgment) [1986] ICJ Reports, para 220.

${ }^{51}$ See Armed Activities on the Territory of the Congo (Democratic Republic of the Congo v Uganda) (Judgment) [2005] ICJ Reports, Separate Opinion of Judge Simma, para 37.

52 See supra, Section II.

${ }^{53}$ See Prosecutor v Zoran Kupreškić, IT-95-16-T, 14 January 2000, para 517.

54 ibid, para 23. For an analysis of this decision in light of the erga omnes character of IHL, see Luigi Condorelli, 'Responsabilité étatique et responsabilité individuelle pour violations graves du droit international humanitaire' in Lal Chand Vohrah et al (eds), Man's Inhumanity to Man: Essays in International Law in Honour of Antonio Cassese (Kluwer Law International 2003) 211.

55 See, generally, Silja Vöneky, 'Implementation and Enforcement of International Humanitarian Law', in Dieter Fleck (ed), The Handbook of International Humanitarian Law (3rd edn, OUP 2013), 647.
} 
and accepted by the adverse Party and has agreed to carry out the functions assigned to a Protecting Power' under IHL. According to common Article 8/8/8/9 of the 1949 Geneva Conventions and Article 5 API, the Protecting Powers have the duty 'to safeguard the interests of the Parties to the conflict'. However, the Protecting Powers are an expression of a general interest of the international community, rather than of interests held only by the belligerents. Indeed, the appointment of Protecting Powers was envisaged as a belligerent's duty pursuant to Article 8/8/8/9 of the 1949 Geneva Conventions and Article 5 API. ${ }^{56}$ The existence of such a duty is in conflict with the alleged care only for the interests of the belligerents: indeed, if only these were relevant, the belligerents would not be prevented from waiving the appointment of Protecting Powers, but rather, they would be allowed to renounce the performance of some functions in only their own interest by mutual consent. On the contrary, the fact that the appointment of Protecting Powers is drafted as mandatory implies that the belligerents' interests are not the only relevant interests, but also that other states are concerned with respect for IHL. Moreover, Article 5(6) API distinguishes the activity of the Protecting Powers regarding IHL implementation from that concerned with diplomatic assistance. In the past, the so-called 'Geneva mandate' (based on the 1949 Geneva Conventions) and 'Vienna mandate' (based on the 1961 Vienna Convention on Diplomatic Relations and the 1963 Vienna Convention on Consular Relations) were performed together. The distinction between the two is reasonable because while the performance of diplomatic relations is primarily based on bilateral relationships, and thus it may be broken if every state considers it no longer satisfactory for its own interests, scrutinising IHL compliance concerns the legal interests of the international community as a whole. Accordingly, the two systems may follow different rules. ${ }^{57}$

\footnotetext{
${ }^{56}$ See Jean Pictet (ed), Commentary: I Geneva Convention Relative to the Protection of Civilian Persons in Time of War (ICRC 1958) 95; François Bugnion, 'Article 8: Protecting Powers' in ICRC (n 46) para 1044.

${ }^{57}$ See Hans-Joachim Heintze, 'Protecting Powers' in MPEPIL online (2009) para 21 (with an erroneous reference to Art 5(5) rather than Art 5(6) API).
} 
In light of the above, it seems that the system of Protecting Powers is a manifestation of shared interests of the international community, similar to those expressed in more general terms by common Article 1 of the 1949 Geneva Conventions. ${ }^{58}$ However, Protecting Powers have been appointed only on few occasions, and, today, one may wonder whether the obligation to appoint them is still a duty, or whether it has been transformed by custom into a power. ${ }^{59}$ However, the decision to adopt provisions regarding the duty to appoint Protecting Powers hints that IHL rules are obligations erga omnes / obligations erga omnes partes, notwithstanding the fact that states have failed to appoint Protecting Powers for political reasons. ${ }^{60}$

In addition, it is noteworthy that Article 90 API introduced the International Humanitarian Fact-Finding Commission, a permanent body of individuals from different countries who, acting in a personal capacity, are tasked with inquiring into grave breaches of the 1949 Geneva Conventions and API, and offering their good offices to belligerents. Although this mechanism of compliance attracted some attention in the 1990s when it was first established, ${ }^{61}$ it has not made a significant contribution to IHL implementation since then, and it is considered a sort of 'sleeping beauty' ${ }^{62}$ Nonetheless, this mechanism is further evidence of a common interest in monitoring IHL implementation, especially since, pursuant to Article 90 API, there is nothing preventing states not directly affected by serious IHL violations from requesting the Commission's intervention. ${ }^{63}$

\footnotetext{
${ }^{58}$ See Benvenuti (n 46) 41; Frédéric Siordet, The Geneva Conventions of 1949: The Question of Scrutiny (ICRC 1953) 71; Henckaerts (n 46) paras 147 and 181.

${ }^{59}$ For more on this, see Robert Kolb, 'Protecting Powers' in Clapham, Gaeta, Sassòli (n 46) 557-560.

${ }^{60}$ See Giulio Bartolini, 'Strengthening Compliance with International Humanitarian Law: The Failed Proposal for a "Meeting of States on International Humanitarian Law" (2015) 25 Italian YIL 202, 204205.

${ }^{61}$ See eg Luigi Condorelli, 'L'inchiesta e rispetto degli obblighi di diritto internazionale umanitario' in Giorgio Badiali (ed), Scritti degli allievi in memoria di G Barile (Cedam 1995) 225, 252-288.

${ }^{62}$ See Frits Kalshoven, 'The International Humanitarian Fact-Finding Commission: A Sleeping Beauty?' (2002) 15 Humanitäres Völkerrecht 213. According to a recent study, the commission was involved in just one armed conflict in 1996 (Heike Spieker, 'International (Humanitarian) Fact-Finding Commission' in MPEPIL online (2015), para 33).

${ }^{63}$ See Luigi Condorelli, 'The Continuity between Certain Principles of Humanitarian Law and the Concept of Crimes of States' in Weiler, Cassese, Spinedi (n 15) 233, 236; August Reinisch, 'The International Fact-
} 


\section{d. Special Rules regarding Derogations, Renunciations, Reprisals, and}

\section{Suspension or Termination due to Material Breaches}

There are other provisions that underscore the fact that contemporary IHL embodies obligations erga omnes / obligations erga omnes partes.

First, according to common Article 6/6/6/7 of the 1949 Geneva Conventions and Article 47 GCIV, no special agreement between the parties to a conflict may reduce the protection offered by the Conventions. These norms function similarly to Article 103 of the UN Charter, dictating the prevalence of the 1949 Geneva Conventions qua treaty law on subsequent agreements. ${ }^{64}$ On the basis of these provisions, a treaty in conflict with the 1949 Geneva Conventions is not void as in cases of conflict with jus cogens, ${ }^{65}$ but rather, the subsequent treaty should be simply disregarded in favour of the 1949 Geneva Conventions. One could wonder why two sovereign states would be prevented from concluding new treaties derogating from previous ones pursuant to Article 30 of the 1969 Vienna Convention on the Law of Treaties (VCLT); the only reasonable answer is that the interests protected by the 1949 Geneva Conventions are the concerns of all the contracting states and, accordingly, they may not be disposed at the will of two states.

Second, according to common Article 7/7/7/8 of the 1949 Geneva Conventions, persons protected 'may in no circumstances renounce in part or in entirety the rights secured to them'. Without entering the complex debate regarding whether this provision implies rights directly conferrable to individuals, suffice it to note that states may not

Finding Commission According to Art 90 Additional Protocol I to the Geneva Conventions and its Potential Enquiry Competence in the Yugoslav Conflict' (1996) 65 Nordic JIL 241, 252-253.

${ }^{64}$ See Robert Kolb, 'Etude sur l'Occupation et sur l'Article 47 de la IVème Convention de Genève du 12 Août 1949 Relative à la Protection des Personnes Civiles en Temps de Guerre: La Degré d'Intangibilité des Droits en Territoire Occupé' [2002] African YIL 297; Lindsey Cameron, 'Commentary to Article 6' in ICRC (n 51).

65 Obviously, if the IHL provision in conflict with a subsequent agreement reflects jus cogens, then the agreement would be void as well. 
invoke the consent of the protected persons in order to justify violations of their rights. ${ }^{66}$ As suggested, the meaning of this provision 'lies in what it reveals of the substantive rules of behaviour enshrined in the Conventions. ${ }^{67}$ It may be argued that the renunciation is not legally valid since the duty to respect IHL is owed to the international community as a whole, rather than towards a specific state or certain individuals.

Third, IHL prohibits reprisals - i.e. countermeasures in response to IHL violations - against protected persons and objects. ${ }^{68}$ This prohibition, reflecting customary international law, ${ }^{69}$ developed especially after the two World Wars, in which atrocities were committed against civilians and prisoners of war under the label of reprisals. ${ }^{70}$ Again, this ban may be explained on the basis of the consideration that actions against protected persons and objects would not only violate the interests of a state which previously breached IHL — in order to make it comply with its obligations — but also the legal interests of every state in the international community. ${ }^{71}$

Fourth, and related to the previous point, a party to the 1949 Geneva Conventions may not invoke a material breach by another party in order to suspend or terminate the

\footnotetext{
${ }^{66}$ See François Buignon, The International Committee of the Red Cross and the Protection of War Victims (Macmillan 2003) 438.

${ }^{67}$ Pierre D'Argent, 'Non-Renunciation of the Rights Provided by the Conventions' in Clapham, Gaeta, Sassòli (n 46) 145, 149.

${ }^{68}$ See Art 46 I GC, Art 47 II GC, Art 13(3) III GC, Art 33(3) IV GC, Artt 20, 51(6), 52(1), 53(c), 54(4), 55(2), and 56(4) API. See also Art 50(1)(c) DARS.

${ }^{69}$ This is the opinion of the ICTY, Prosecutor v Zoran Kupreškić (n 53) para 531; Prosecutor v Milan Martić, IT-95-11-R61, 8 March 1996, para 10. Since some states still today consider that, under exceptional circumstances, civilians may be subject to reprisals in the course of hostilities (see Customary IHL (n 43), 520-522), the ICRC considers that the ban on reprisals against protected persons is customary in character (ibid 519-520), while there is a strong trend towards the crystallisation of a customary ban on reprisals against civilians in the conduct of hostilities (ibid 523).

70 On this topic, see, generally, Frits Kalshoven, 'Belligerent Reprisals Revisited' [1990] 21 Netherlands YIL 43; Jérôme de Hemptinne, 'Prohibition of Reprisals' in Clapham, Gaeta, Sassòli (n 46) 575.

${ }^{71}$ The Special rapporteur Gaetano Arangio-Ruiz proposed a general ban on countermeasures regarding obligations erga omnes and obligations erga omnes partes in 'Fourth Report on State Responsibility' [1992-II] YILC paras 92-95. See also Serena Forlati, Diritto dei trattati e responsabilità internazionale (Giuffrè 2005) 114.
} 
application of the 1949 Geneva Conventions pursuant to Article 60 VCLT. $^{72}$ In fact, Article 60(5) expressly excludes this rule's applicability 'to provisions relating to the protection of the human person contained in treaties of a humanitarian character, in particular to provisions prohibiting any form of reprisals against persons protected by such treaties.' Article 60(5) was first proposed by the Swiss representatives at the UN Conference on the Law of Treaties, who mentioned the ban on reprisals embodied in the 1949 Geneva Conventions and the need to protect human beings as reflected in IHL and other branches of international law. ${ }^{73}$ It is clear that this provision, which is applicable also to human rights treaties, covers the 1949 Geneva Conventions and API, which are treaties that protect human beings, that are of a humanitarian character, and that ban reprisals against protected persons. ${ }^{74}$ Article 60(5) VCLT arguably addresses obligations erga omnes partes; a common interest among the contracting states one of the principal arguments explaining why treaties such as the 1949 Geneva Conventions may not be suspended or terminated in response to material breaches. ${ }^{75}$

All of the above mechanisms are related to the erga omnes or erga omnes partes nature of IHL obligations rather than to their alleged peremptory nature. Indeed, common Article 6/6/6/7 of the 1949 Geneva Conventions and Article 47 GCIV do not prescribe the invalidity of a treaty conflicting with IHL conventions - which would be the effect of a conflict with jus cogens. Similarly, the ban on belligerent reprisals and the inapplicability of the rule on material breach do not depend on the ascertainment of the peremptory nature of IHL provisions case-by-case. In particular, the inapplicability of the rule on material breach pertains to all provisions relating to the protection of the human persons

\footnotetext{
72 The ILC itself notes the link between the ban of reprisals and Art 60(5) VCLT in DARS, Commentary to Art 50, para 8. For more on this, see Linos-Alexander Sicilianos, 'The Relationship between Reprisals and Denunciation or Suspension of a Treaty' (1993) 4 EJIL 341; Pauwelyn (n 10) 913-914.

${ }^{73}$ See UN Conference on the Law of Treaties: Official Records vol I (New York 1969) 354-355.

${ }^{74}$ See Bruno Simma, Christian J Tams, 'Article 60 - Convention de 1969' in Olivier Corten, Pierre Klein (eds), Les Conventions de Vienne sur le droit des traités: Commentaire article par article (Bruylant 2006) 2131, 2157-2161; Thomas Gigerich, 'Article 60' in Oliver Dörr, Kirsten Schmalenbach (eds), Vienna Convention on the Law of Treaties: A Commentary ( $2^{\text {nd }}$ edn, Springer 2018) 1095, 1122.

${ }^{75}$ See Condorelli, Boisson De Chazournes, 'Quelques' (n 45) 21; Picone, 'Obblighi reciproci' (n 2) 34-35; Forlati (n 71) 141.
} 
in IHL, even with regard to those API provisions which do not have customary status. The reason for such departures from the general law of treaties and the law of international responsibility seems to be rooted in the nature of the legal interests protected by IHL provisions.

\section{e. The Prosecution of War Crimes}

Although this is not the occasion to analyse fully the role of obligations erga omnes in international criminal law, a brief reflection is needed to demonstrate that IHL compliance through criminal prosecution concerns the international community as a whole. ${ }^{76}$

Contracting states have a duty to provide for effective criminal sanctions for persons responsible for grave breaches of the 1949 Geneva Conventions and API, or to hand those persons over to another contracting state for trial. ${ }^{77}$ The drafters of the 1949 Geneva Conventions aimed to repress grave breaches of IHL irrespective of a jurisdictional link between the alleged offences and the seat of adjudication. This is demonstrated by the fact that, according to the 1949 Geneva Conventions, in case of extradiont it is sufficient that the requesting state has a prima facie case, and that the surrender complies with domestic legislation. Accordingly, the rule aut dedere aut judicare does not satisfy the interest of a state particularly concerned with the alleged crimes - as would be the case if the 1949 Geneva Conventions would have required a jurisdictional link for the surrender - but rather, it aims at the punishment of IHL violations per se, a task that may be performed by every contracting state - i.e. every state in the international community given the universal ratification of the 1949 Geneva Conventions.

76 See, generally, Emanuele Cimiotta, 'The Relevance of Erga Omnes Obligations in Prosecuting International Crimes' (2016) 76 ZaöRV 661.

77 Artt 49-50 GCI, Artt 50-51 GCII, Artt 129-130 GCIII, Artt 146-147 GCIV, Art 85 API. On this topic, see, among others, Paola Gaeta, 'Grave Breaches of the Geneva Conventions' in Clapham, Gaeta, Sassòli (n 46) 615 . 
That the rule aut dedere aut judicare regards legal interests of the international community as a whole or of a group of contracting states was also confirmed by the ICJ with reference to the corresponding provision embodied in the UN Convention against Torture, ${ }^{78}$ in a dispute that was kindled by a Belgian court's decision to prosecute Hisséne Habré for international crimes, including war crimes. ${ }^{79}$ This conclusion was also somewhat acknowledged - albeit very timidly — by the ILC in a recent study on the obligation aut dedere aut judicare. ${ }^{80}$

In addition, the entire doctrine of the principle of universal jurisdiction regarding international crimes, including war crimes, ${ }^{81}$ may be read as implying that the state that commences a trial has an interest in the prosecution of those criminal acts, even in the absence of a traditional jurisdictional link. This interest might derive from the fact that the breached norms are obligations erga omnes / obligations erga omnes partes, ${ }^{82}$ even if states with legislation regarding universal jurisdiction have not openly invoked these kinds of obligations to justify the exercise of universal criminal jurisdiction. ${ }^{83}$

\footnotetext{
${ }^{78}$ See Belgium v Senegal (n 36) paras 68-70, in which the ICJ based the Belgian locus standi on the fact that the Convention against Torture embodies obligations erga omnes partes. For more on the relationship between obligations erga omnes partes and the principle aut dedere aut judicare in this decision, see Emanuele Cimiotta, "Aut dedere aut judicare, universalità "condizionata" e Convenzione contro la tortura: a margine del caso Belgio c Senegal' (2013) 7 Diritti umani e diritto internazionale 105.

${ }^{79}$ See Belgium v Senegal (n 36) paras 19, 21, 54.

${ }^{80}$ See 'Final Report on The Obligation to Extradite or Prosecute (Aut Dedere Aut Judicare)' (2014) <legal.un.org/ilc/texts/instruments/english/reports/7_6_2014.pdf>.

${ }^{81}$ On universal jurisdiction and grave breaches of IHL, also for references to the relevant case law and domestic legislation, see Roger O'Keefe, 'The Grave Breaches Regime and Universal Jurisdiction' (2009) 7 JICJ 811.

${ }^{82}$ See eg Rosanne van Alebeek, 'The Pinochet Case: International Human Rights Law on Trial' [2000] 71 BYIL 29, 34; Harmen van der Wilt, 'Universal Jurisdiction under Attack. An Assessment of African Misgivings towards International Criminal Justice as Administered by Western States' (2011) 9 JICJ 1043, 1050-1051; Sienho Yee, 'Universal Jurisdiction: Concept, Logic, and Reality' (2011) 10 Chinese JIL 503, 505.

${ }^{83}$ See Tams, 'Enforcing' (n 2) 10.
} 


\section{The Convergence of Secondary Norms on IHL Violations and the Law of State Responsibility regarding Serious Violations of Obligations Erga Omnes and Obligations Erga Omnes Partes}

This section argues that the the rules on serious violations embodied in IHL conventions and the relevant state practice is consistent with the rules on state responsibility concerning the consequences of violations of obligations erga omnes / obligations erga omnes partes, so that the two systems appear to have converged to similar solutions.

As mentioned above, indirectly affected states may invoke the responsibility of another state, claim cessation of the wrongful act, claim assurances of non-repetition, and claim performance of the obligation of reparation on behalf of the directly injured state or the beneficiaries of the obligation violated. Moreover, they shall not recognise the consequences of serious violations of obligations erga omnes. Finally, peaceful countermeasures may be undertaken, although there is no general consensus regarding forcible countermeasures. ${ }^{84}$

State practice regarding serious IHL violations is ripe with reactions of indirectly affected states. Limiting this analysis to the most recent state practice, it is possible to find several individual condemnations and requests for cessation from indirectly affected states, e.g. in the cases of the Iran-Iraq conflict, ${ }^{85}$ the Rwandan genocide, ${ }^{86}$ the war in Bosnia, ${ }^{87}$ the ethnic cleansing in Kosovo, ${ }^{88}$ the Iraqi invasion of Kuwait, ${ }^{89}$ the Libyan

\footnotetext{
${ }^{84}$ See above Section II for a discussion on these issues.

${ }^{85}$ Spain, 'Comunicado del Gobierno expresando su preocupacíon por el conflicto bélico entre Irán e Irak' (15 March 1988) quoted in Customary IHL (n 43) vol II 41.

${ }^{86}$ See, e.g., France, 'Communiqué of the Ministry of Foreign Affairs regarding Rwanda' (17 July 1994) quoted in Customary IHL (n 43) vol II 37.

${ }^{87}$ See, e.g., the 1993 Franco-German Declaration on the War in Bosnia and Herzegovina quoted in Customary IHL (n 43) vol II 24; Netherlands, 'Letters from the Minister of Foreign Affairs' (11 February 1994 and 27 July 1995) quoted in Customary IHL (n 43) vol II 40.

${ }^{88}$ France, 'Reply by Pierre Moscovici, Ministre Délegué for European Affairs, to a question in parliament' (19 January 1999) quoted in Customary IHL (n 43) vol II 37.

${ }^{89}$ See, e.g., 'Address to the UN General Assembly by President George HW Bush' (1 October 1990) <www.state.gov/p/io/potusunga/207268.htm>; 'League of the Arab States, Res/5038/ES (31 August 1990)' in Elihu Lauterpacht et al (eds), The Kuwait Crisis: Basic Documents (Grotius 1991) 296.
} 
civil war, ${ }^{90}$ the Syrian civil war, ${ }^{91}$ and the ongoing Israeli-Palestinian conflict. ${ }^{92}$ Similarly, one may take into proper consideration states' votes approving General Assembly's and Security Council's resolutions condemning IHL violations as manifestations of states' opinio juris. ${ }^{93}$

Scholars have suggested that indirectly affected states may adopt countermeasures in response to serious IHL violations since the codification of modern jus in bello. ${ }^{94}$ The practice regarding countermeasures adopted by indirectly affected states when IHL is seriously violated is quite scarce, but it does exists. Recent practice regards the 2011 Libyan civil war, when, prior to the adoption of UN sanctions, Switzerland and the US froze the assets of both Gaddafi and the Libyan Central Bank, while the Arab League suspended Libya's membership even in the absence of justification under its Charter. ${ }^{95}$ Similarly, during the Syrian civil war, the EU, the Arab League, and some non-EU

\footnotetext{
${ }^{90}$ See, e.g., Barack Obama, 'Remarks by the President in Address to the Nation on Libya' (28 March 2011) <www.whitehouse.gov/the-press-office/2011/03/28/remarks-president-address-nation-libya>.

${ }^{91}$ See the position of Germany, Kuwait, Norway, and UK in 'Co-Hosts Declaration of the Supporting Syria and The Region Conference, London 2016' (4 February 2016) <www.gov.uk/government/uploads/system/uploads/attachment_data/file/498040/Supporting_Syria_the_ Region_London_2016_-_Co-hosts_Declaration_penultimate_.pdf>.

${ }^{92}$ See, e.g., the reaction to the 2014 Gaza War of Belgium, 'Didier Reynders Calls for a Ceasefire Between Gaza and Israel' (15 July 2014) <countries.diplomatie.belgium.be/en/nigeria/newsroom/news.jsp?id=252669>; Brazil, 'Conflict between Israel and Palestine' <www.itamaraty.gov.br/en/ficha-pais/42-diplomacia-publica/notas-aimprensas/5714-conflict-between-israel-and-palestine>.

${ }^{93}$ For the UN bodies condemnations of IHL violations, see eg SC Res 540, UN Doc S/RES/540, 31 October 1983; SC Res 876, UN Doc S/RES/876, 19 October 1993; SC Res 1973, UN Doc S/RES/1973, 17 March 2011; UN GA Res 60/105, UN Doc A/RES/60/105, 8 December 2005 (which has been repeated almost identically every year, the last in UN GA Res 70/88, A/RES/70/88, 15 December 2015).

${ }^{94}$ See, eg, Lassa Oppenheim, International Law, a Treatise, vol I (2nd edn, Longman 1912) 191.

${ }^{95}$ See Swiss Federal Council, 'Ordonnance instituant des mesures à l'encontre de certaines personnes originaires de la Libye' (21 February 2011) <www.admin.ch/opc/fr/classifiedcompilation/20110418/201103110000/946.231.149.82.pdf >; President Obama's Executive Order 13566 of $25 \quad$ February 2011 <www.treasury.gov/resourcecenter/sanctions/Programs/Documents/2011_libya_eo.pdf>; 'Arab League Bars Libya From Meetings, Citing Forces' Crimes', Bloomberg News (22 February 2011) <www.bloomberg.com/news/articles/201102-22/arab-league-bars-libya-from-meetings-citing-forces-crimes>.
} 
countries adopted sanctions against Syria. ${ }^{96}$ All these measures appear to be illegal under the statutes of the relevant organisations, ${ }^{97}$ international trade and investment law, and the principle of non-intervention. ${ }^{98}$ It has been suggested that these actions are countermeasures in response to serious IHL violations pursuant to Articles 48 and 54 DARS. ${ }^{99}$

Moreover, some states have declared that the 1949 Geneva Conventions impose the responsibility to 'take steps to ensure the respect of these humanitarian rules in all circumstances by other States, even if they are not themselves directly involved in an armed conflict' ${ }^{100}$ A similar opinio juris was also manifested by states in a questionnaire prepared by the ICRC, ${ }^{101}$ and by General Assembly's and Security Council's resolutions. ${ }^{102}$ Finally, after having affirmed in the Wall advisory opinion that Israel had violated certain obligations erga omnes, the ICJ added that 'all the States parties to [GCIV] [...] are under an obligation, while respecting the [UN] Charter and international

96 See eg Council Decision 2011/273/CFSP of 9 May 2011 [2011] OJ L 121/11; Council Decision 2011/782/CFSP of 1 December 2011 [2011] OJ L 319/56; 'Isolating Syria, Arab Leagues Approves Imposes Broad Sanctions', The New York Times (27 November 2011) <www.nytimes.com/2011/11/28/world/middleeast/arab-league-prepares-to-vote-on-syrian-

sanctions.html?_r=0>; President Obama's Executive Orders 13573 (18 May 2011) and 13582 (17 August 2011) <www.treasury.gov/resource-center/sanctions/Programs/pages/syria.aspx>; Australian Department of Foreign Affairs and Trade, 'Australia's Autonomous Sanctions: Syria' (13 May 2011) <www.dfat.gov.au/un/unsc_sanctions/syria_autonomous_sanctions.html>; Swiss State Secretariat for Economic Affairs, 'Mesures à l'encontre de la Syrie' (18 May 2011) <www.seco.admin.ch/themen/00513/00620/00622/04669/index.html>.

97 See Martin Dawidowicz, 'Third-Party Countermeasures: A Progressive Development of International Law?' (2016) 29 Zoom In, Questions of International Law 3, 5-7 <www.qil-qdi.org/wpcontent/uploads/2016/06/02_Collective-CM_DAWIDOWICZ.pdf>.

${ }^{98}$ For the prima facie illegality of asset freezing measures, see Evan J Criddle, 'Humanitarian Financial Intervention' (2013) 24 EJIL 583, 590-593.

${ }^{99}$ See Dawidowicz, 'Third-Party Countermeasures: A Progressive Development' (n 97) 11-15.

${ }^{100}$ Human Rights in Armed Conflicts, Res XXIII adopted by the International Conference on Human Rights, 12 May 1968, preamble.

${ }^{101}$ As quoted in Antonio Cassese, 'Remarks on the Present Legal Regulation of Crimes of States' in Weiler, Cassese, Spinedi (n 15) 200, 208-210.

102 See eg UN SC Res 681, UN Doc S/RES/681, 20 December 1990; UN SC Res 764, UN Doc S/RES/764, 13 July 1992; UN SC Res 955, UN Doc S/RES/955, 6 November 1994; UN GA Res 60/105 (n 93) para 3 (and the identical texts in the yearly resolution regarding the Palestinian Territory, eg UN GA Res 70/88 (n 93) para 3). 
law, to ensure compliance by Israel with IHL as embodied in that Convention', ${ }^{103}$ but it is doubtful whether this sentence refers to countermeasures. ${ }^{104}$

With regard to the minority view according to which the use of force as a countermeasure may be lawful under certain conditions, suffice it to say that serious IHL violations are mentioned as breaches that might allow such reactions, ${ }^{105}$ even in the context of the doctrine of the Responsibility to Protect. ${ }^{106}$ Even the 2017 and 2018 US, UK, and French bombings against a Syrian air force base and some industrial compounds may be considered as third states' countermeasures in response to serious violation of IHL obligations erga omnes, even if these attacks are clearly unlawful. ${ }^{107}$

As to the duty to cooperate to bring to an end to certain serious violations pursuant to Article 41 DARS, which, as already mentioned, should be read as referring to obligations erga omnes as well, ${ }^{108}$ it should be noted that Article 89 API clearly states that '[i]n situations of serious violations of the Conventions or of this Protocol, the High Contracting Parties undertake to act jointly or individually, in co-operation with the [UN] and in conformity with the [UN] Charter.' Even if the text of Article 41 DARS does not refer directly to the UN, it is generally accepted that in cases of serious violations of obligations erga omnes an institutional reaction by an international organisation or a body that represents the interests of the international community as a whole or the contracting

\footnotetext{
103 Wall opinion (n 29), para 159.

104 See Section V.

105 See eg Picone 'Unilateralismo' (n 24) 26.

106 See International Commission on Intervention and State Sovereignty, The Responsibility to Protect, December 2001, <responsibilitytoprotect.org/ICISS\%20Report.pdf> para 4.20. On the relationship between common Article 1 of the 1949 Geneva Conventions and the Responsibility to Protect, see Laurence Boisson de Chazournes, Luigi Condorelli, 'De la responsabilité de protéger, ou d'une nouvelle parure pour une notion déjà bien établie' (2006) 110 RGDIP 11. However, this author believes that the doctrine of the Responsibility to Protect does not permit the use of armed force beyond the limits posed by the UN Charter. ${ }^{107}$ For the background of these operations and the reasons why they should be considered illegal, see Marko Milanovic, 'The Clearly Illegal US Missile Strike in Syria', EJIL: Talk! (7 April 2017) <www.ejiltalk.org/the-clearly-illegal-us-missile-strike-in-syria/>; Jack Goldsmith, Oona Hathaway, 'Bad Legal Arguments for the Syria Strikes', Just Security (14 April 2018) <www.justsecurity.org/54925/badlegal-arguments-syria-strikes/>.

${ }^{108}$ See above, Section II and, in particular, n 14.
} 
states would be more advisable. ${ }^{109}$ In this respect, the Security Council is considered the most appropriate institutional actor to coordinate these reactions. ${ }^{110}$ Article 89 API conveys this idea in the field of IHL, ${ }^{111}$ even if IHL implementation originally was outside the scope of the Security Council's action. ${ }^{112}$ Moreover, according to a commentator, the UN ad hoc International Criminal Tribunals for Rwanda and the former Yugoslavia may be seen as the reaction of the international community, acting through the Security Council, against serious IHL violations committed in those countries. ${ }^{113}$ Similarly, it has been argued that Security Council referrals in the ICC Statute may be considered expressions of a similar reaction against violations of obligations erga omnes, including war crimes. ${ }^{114}$ Furthermore, another institutional actor for cooperation in response to serious IHL violations may be seen in the Conference of the High Contracting Parties to GCIV held in Geneva on 5 December 2001 pursuant to common Article 1 of the 1949 Geneva Conventions. ${ }^{115}$

\footnotetext{
109 The coordination of the UN in these cases has been foreseen by Ago in 'Eighth Report on State Responsibility' [1979-II] ILCY 43-44. The Special rapporteur Arangio-Ruiz attempted to link the ascertainment of the commission of a crime of state to a determination of the SC, the AG, or the ICJ ('Seventh Report on State Responsibility' [1995-II] YILC paras 70-120).

${ }^{110}$ See 2005 World Summit Outcome, GA Res 60/1, UN Doc a/RES/60/1, 16 September 2005, para 139. It has been argued that, in similar cases, the SC may be seen both as an organ of the UN and the material organ of the international community as a whole (Paolo Picone, 'Gli obblighi erga omnes tra passato e futuro' (2015) 98 RDI 1081, 1083, 1092-1093, with references also to previous writings. See also the statement of the Libyan representative during a debate on IHL and the protection of civilians in armed conflict: 'The international community, represented mainly by this Council...' (UN SCOR, 64th Ses, 6151st mtg at 20, UN Doc S/PV.6151 (26 June 2009)).

111 On countermeasures undertaken pursuant to Art 89 API, see Benvenuti (n 46) 45. On the relationship between Art 89 API and 41 DARS, see Sassòli (n 2) 428-430.

112 On the progressive involvement of the Security Council in IHL implementation, see Marco Roscini, 'The United Nations Security Council and the Enforcement of International Humanitarian Law' (2010) 43 Israel LR 330.

${ }^{113}$ Paolo Picone, 'Sul fondamento giuridico del Tribunale penale per l'ex-Iugoslavia' in Flavia Lattanzi, Elena Sciso (eds), Dai tribunali penali ad hoc ad una corte permanente (Editoriale Scientifica 1996) 73.

114 Paolo Picone, 'Corte penale internazionale e crimini internazionali degli Stati' in Società Italiana di Diritto Internazionale (ed), Cooperazione fra Stati e giustizia penale internazionale (Editoriale Scientifica 1999) 73.

${ }^{115}$ See Sassòli (n 2) 429.
} 


\section{Conclusions}

In light of the above, it is reasonable to argue that IHL should be seen as an 'atelier d'expérimentation juridique' ${ }^{116}$ regarding the law of state responsibility applicable to obligations erga omnes and obligations erga omnes partes. Not only, it has been argued, does IHL embody obligations erga omnes and obligations erga omnes partes, but also state practice and treaty law provide secondary rules on serious IHL violations that are very similar to those subsequently codified by the ILC. Admittedly, it is difficult to prove that these IHL provisions were directly employed as a model for the development of the law of state responsibility on serious violations of obligations erga omnes and obligations erga omnes partes; however, this conclusion is suggested by the similarities between practice in response to violations of IHL and the secondary rules arising in response to violations of obligations erga omnes codified by the ILC. The influence of IHL on the law of state responsibility here can be viewed alongside other regimes, such as that embodied in the Genocide Convention. As one commentator has noted, there is a continuity between IHL and general international law in relation to the consequences of serious violations. ${ }^{117}$

\footnotetext{
116 This expression is borrowed from Luigi Condorelli, 'Le droit international humanitaire en tant qu' atelier d'expérimentation juridique' in Walter Haller et al (ed), Im Dienst an der Gemeinschaft. Festschrift für Dietrich Schindler, zum 65. Geburtstag (Helbing \& Lichtenhahn 1989) 193.

${ }^{117}$ See Condorelli, 'The Continuity' (n 63).
} 